\title{
A Mississippian trackway (Pseudobradypus ichnosp.) from the Enragé Formation, New Brunswick, Canada
}

\author{
Nadine J. Wood and Randall F. Miller* \\ Steinhammer Palaeontology Laboratory, Natural Science Department, New Brunswick Museum, \\ Saint John, New Brunswick E2K 1E5, Canada \\ *Corresponding author: <Randall.Miller@nbm-mnb.ca >
}

Date received: 14 November 2006 Date accepted: 01 October 2007

ABSTRACT

A tetrapod trackway, identified as Pseudobradypus ichnosp., from the Upper Mississippian Enragé Formation represents one of the few occurrences of fossil vertebrate tracks documented in New Brunswick. It was collected from red mudstone near Green Creek, Upper Rockport, New Brunswick on the Maringouin Peninsula. The Enragé Formation is Namurian age and is the top of the Mabou Group in New Brunswick. As Pseudobradypus is often attributed to a captorhinomorph reptile trackmaker, this specimen may be considered among the early evidence for reptiles (amniotes).

RÉSUMÉ

Un sillon de tétrapode, identifié à titre de Pseudobradypus ichnosp., de la Formation du Mississippien supérieur d'Enragé, représente l'un des rares cas de présence d'empreintes de vertébré fossile documentés au Nouveau-Brunswick. On a prélevé ces empreintes dans du mudstone rouge près de la crique Green, à Upper Rockport(Nouveau-Brunswick), sur la péninsule de Maringouin. La Formation d'Enragé remonte au Namurien et se trouve au sommet du groupe de Mabou au Nouveau-Brunswick. Comme on rattache souvent le Pseudobradypus à un reptile captorhinomorphe auteur d'empreintes, ce spécimen peut être considéré comme l'un des premiers signes de la présence des reptiles (amniotes).

[Traduit par la redaction]

\section{INTRODUCTION}

Fossil vertebrate footprints are rare in New Brunswick, with only four previously documented localities. All the specimens represent Mississippian-Pennsylvanian footprints or trackways. Only one occurrence has been adequately described, while the other identifications are inadequate or considered dubious. A single undescribed trackway in the Canadian Museum of Nature (CMN 10013) from the Mississippian (Namurian) Bonaventure Formation of Heron Island northern New Brunswick (Ells 1881; Harington et al. 2005) is identified only as 'Amphibia?'. All other specimens are in the collection of the New Brunswick Museum (NBMG). A putative Triassic trackway identified as Isocampe lepreauense (NBMG 3044) from the Balls Lake Formation at Lepreau Falls (Sarjeant and Stringer 1978) requires reexamination as the rocks are now assigned to the Mississippian Mabou Group (Barr and White 2005). Footprints from the Pennsylvanian (Langsettian) Lancaster Formation, 'Fern Ledges' locality in Saint John, described by Matthew (1910) have been considered to be unrecognizable by various authors (e.g., Falcon-Lang and Miller 2007). Bipezia, represented by Bipezia bilobata (NBMG 3037-3038), was described as unrecognized "genera" by Häntzschel(1975) who considered it to be of doubtful vertebrate origin based on Matthew's description. Glaessner (1957) thought it might be synonymous with the arthropod trace Isopodichnus (= Oniscoidichnus). Both Hylopus, represented by Hylopus(?) variabilus, (NBMG 3041-3043) and Nanopus, represented by Nanopus(?) vetustus, (NBMG 3045) were considered as unrecognized "genera" and considered as doubtful "footprints" by Häntzschel (1975). Abel (1935) believed neither represented a vertebrate track, but were unrecognizable forms. Falcon-Lang et al. (2007) described a fourth locality near Johnson Mills in the Pennsylvanian (Langsettian) Grande Anse Formation from the Maringouin Peninsula in southeastern New Brunswick. They identified most of the tracks on two slabs as Pseudobradypus (NBMG 14143, 14144).

The footprints described here, from the Upper Mississippian (Namurian) Enragé Formation, Upper Rockport, New Brunswick, represent a significant addition to the meagre record of Paleozoic tetrapod tracks from New Brunswick (Fig. 1). The specimen is referred to Pseudobradypus ichnosp., and represents one of the oldest tetrapod ichnofossils from New Brunswick. The oldest occurrence of Pseudobradypus is from 
the Lower Mississippian (Tournaisian) Horton Bluff Formation in Nova Scotia where Lucas et al. (2004) described the oldest known tetrapod trackways from the Maritime Provinces. Most Pseudobradypus are attributed to captorhinomorph reptiles (Haubold 1971). Falcon-Lang et al. (2007) argued that Pseudobradypus from the Grande Anse Formation could convincingly be attributed to a reptile trackmaker and thus provides the earliest evidence for reptiles.

Tetrapod footprints are well known from Nova Scotia in the Maritimes region of eastern Canada, some of the earliest work being done by Sir William Dawson and others from the cliffs at Joggins (Sarjeant and Mossman 1978). Ironically George Frederic Matthew at the Natural History Society of New Brunswick in Saint John, who identified the dubious footprints from the 'Fern Ledges' site, set the pace for the study of Carboniferous tetrapod ichnology (Matthew 1903a,b, 1905; Haubold et al. 2005) by attempting to develop a classification framework for tracks. Most of his work involved Nova Scotia specimens. Haubold et al. (2005) noted that in the 100 years since Matthew's work there has been little progress in finding a suitable classification scheme.

\section{LOCATION AND GEOLOGY}

The type section of the Enragé Formation is exposed along the southwest shoreline of the Maringouin Peninsula, Westmorland County, New Brunswick (NTS 21 H/10E). The specimen described here was found during the NATMAP field trip (St. Peter and Johnson 1997, STOP 11E) on a coastal exposure on the east side of the Maringouin Peninsula, along the western shore of the Cumberland Basin about half a kilometre south-southwest of Green Creek (Fig. 1). The trackway was collected from a vertical face of brick red mudrock at the top of the last fining-upward cycle of the Enragé Formation, which also represents the top of the Mabou Group in New Brunswick (Fig. 2).

The Enragé Formation consists of fine-to coarse-grained, reddish orange arkosic grit, pebbly grit, arkosic sandstone, polymictic conglomerate and brick red siltstone and mudstone (St. Peter and Johnson 1997; New Brunswick Department of Natural Resources 2007). Sandstone beds, 1 to 5 metres thick, form repeated fining-upward cycles that are 4-10 metres thick. Red siltstone and mudstone form the upper 5-12 centimetres

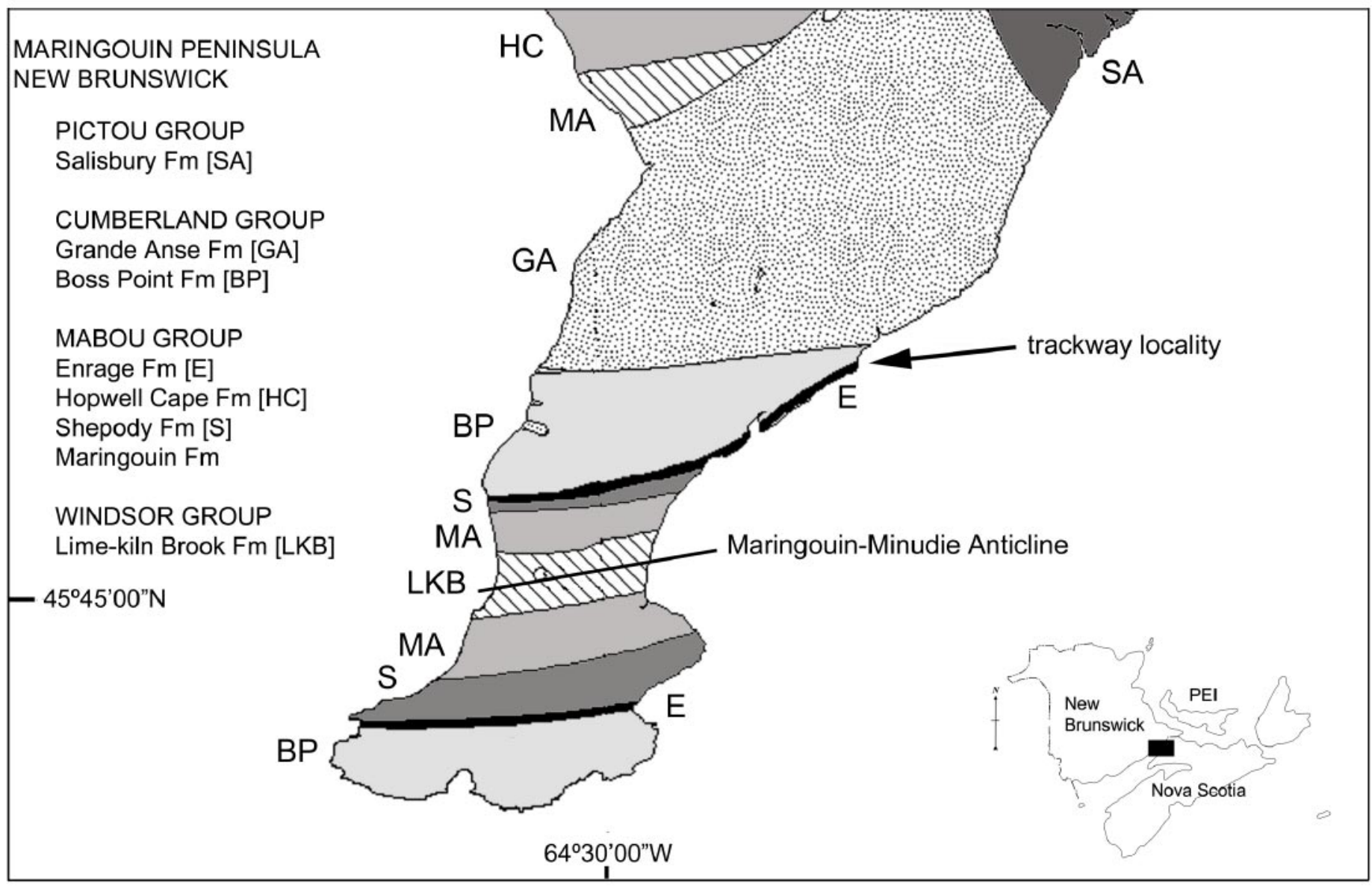

Fig. 1 Location and local stratigraphy of the tetrapod trackway in the Mississippian, Enragé Formation near Green Creek, Upper Rockport, New Brunswick. 
of each fining-upward cycle. The Enragé Formation of the Mabou Group occupies the stratigraphic interval immediately below the Cumberland Group in New Brunswick and is, in part, laterally equivalent to the Hopewell Cape Formation. An unconformity separates the Enragé Formation from the overlying Boss Point Formation (Fig. 2).

Spores from the Enragé Formation suggested an age no younger than Namurian (reported in St. Peter and Johnson 1997) from a locality near the top of the formation at Green Creek. The assemblage was considered too poor to date with confidence, and the formation age is reported as unspecific Namurian age. Calder et al. (2005) placed the Enragé Formation in the Pendleian just below the unconformity between the Mississppian and Pennsylvanian of the Maritimes.

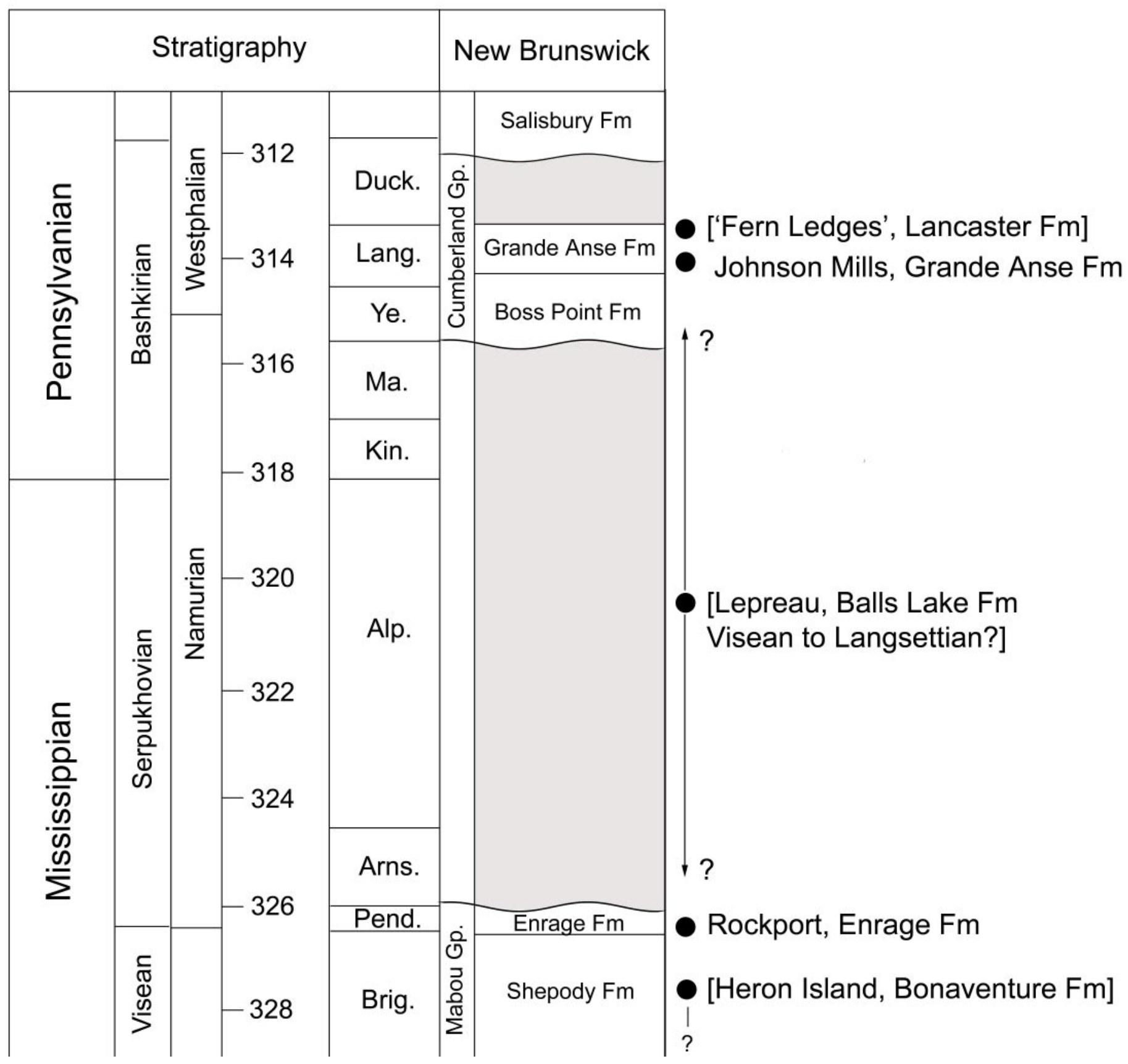

Fig. 2 Stratigraphy of the lower Maringouin Peninsula, and the position of tetrapod tracks in New Brunswick. Localities in square brackets are outside the Maringouin Peninsula area. 


\section{SYSTEMATIC PALAEONTOLOGY}

\section{Ichnogenus Pseudobradypus Matthew, 1903a Pseudobradypus ichnosp.}

Fig. 3, 4

Material examined: The tracks were found by M. Gibling (Dalhousie University) and students during the 1997 NATMAP field trip described in a field guide by St. Peter and Johnson (1997). The trackway was collected and is preserved on slab NBMG 10128/3 (Fig. 3), which includes nine or more footprints. NBMG 10128/1, 2 are counterparts to the slab. The single print NBMG 10128/2 (Fig. 4), was collected during the field trip by R.F. Miller and J.H. McGovern, and the larger slab recovered later by D. Mossman. The specimen is deposited at the New Brunswick Museum (NBMG), Saint John, Canada.
Locality: On the east side of the Maringouin Peninsula(Fig. 1), southwest of Green Creek, Upper Rockport (approximately $45^{\circ} 46^{\prime} 47^{\prime \prime} \mathrm{N} ; 64^{\circ} 26^{\prime} 00^{\prime \prime} \mathrm{W}$ ), along the western shore of the Cumberland Basin, in Westmorland County, New Brunswick. The site is described in the NATMAP field guide as STOP 11E (St. Peter and Johnson 1997).

Age: Mississippian, Namurian (326.4 <http://www.stratigraphy. org/geowhen/timelinestages.html> to $315<\mathrm{http}: /$ www. stratigraphy.org/geowhen/region_all.html> Ma), Enragé Formation (St. Peter and Johnson 1997).

Footprint characteristics: The pes footprints are pentadactyl and semi-plantigrade. Digits increase in length from I to IV, with digit $\mathrm{V}$ laterally extended and approximately the same length as digit IV (Table 1). Pads of digits are not pronounced.
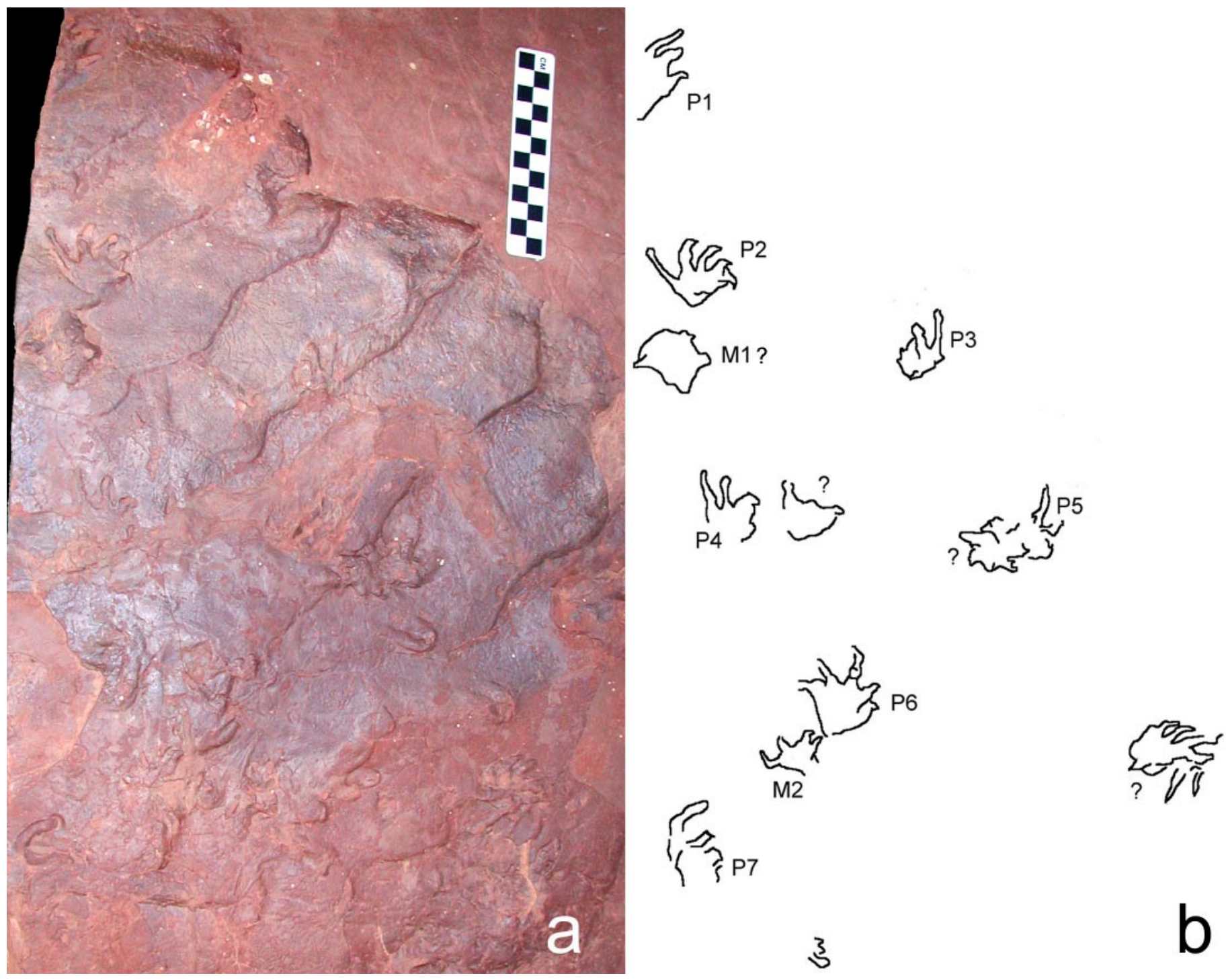

Fig. 3 Trackway of Pseudobradypus ichnosp. (a) photograph of NBMG 10128/3, showing footprint impressions in convex hyporelief, lighting from top left. Scale bar $12 \mathrm{~cm}$ long. (b) Map of footprints. Pes footprints indicated by 'P', manus footprints indicated by ' $M$ '. Scale bar $12 \mathrm{~cm}$. 
Claws of digits I to IV acuminate and curve inward. Digits I to IV also curve slightly inward, but digit $V$ remains straight. The tip of digit $\mathrm{V}$ is bulbous and straight. The sole length is up to $16 \mathrm{~mm}$, and the sole width is up to $28 \mathrm{~mm}$. It is round towards the bottom. Pes lengths are up to $40 \mathrm{~mm}$, and pes widths are up to $43 \mathrm{~mm}$. There is one well-preserved pes footprint (Fig. 4) (footprint P2 on the trackway specimen, NBMG 10128/3) and its counterpart (NBMG 10128/2).

The manus is smaller than the pes, and preserved once behind pes, P6. Only four digits appear on the manus (Fig. 3 ), increasing in length from I to IV, and curving inward. Digit tips are incomplete. Manus length measures $25 \mathrm{~mm}$, and manus width measures $35 \mathrm{~mm}$. Palm length measures $11 \mathrm{~mm}$, and palm width measures $20 \mathrm{~mm}$. Due to a lack of preserved mani, the number of digits and the overall size and shape of the manus is ambiguous.

Trackway characteristics: The trackway is poorly preserved, consisting mainly of pes footprints with one manus footprint having some distinguishable digits preserved behind one of the pes footprints (Fig. 3). Footprint M1, located behind the pes footprint $\mathrm{P} 2$, is poorly preserved and immeasurable. All
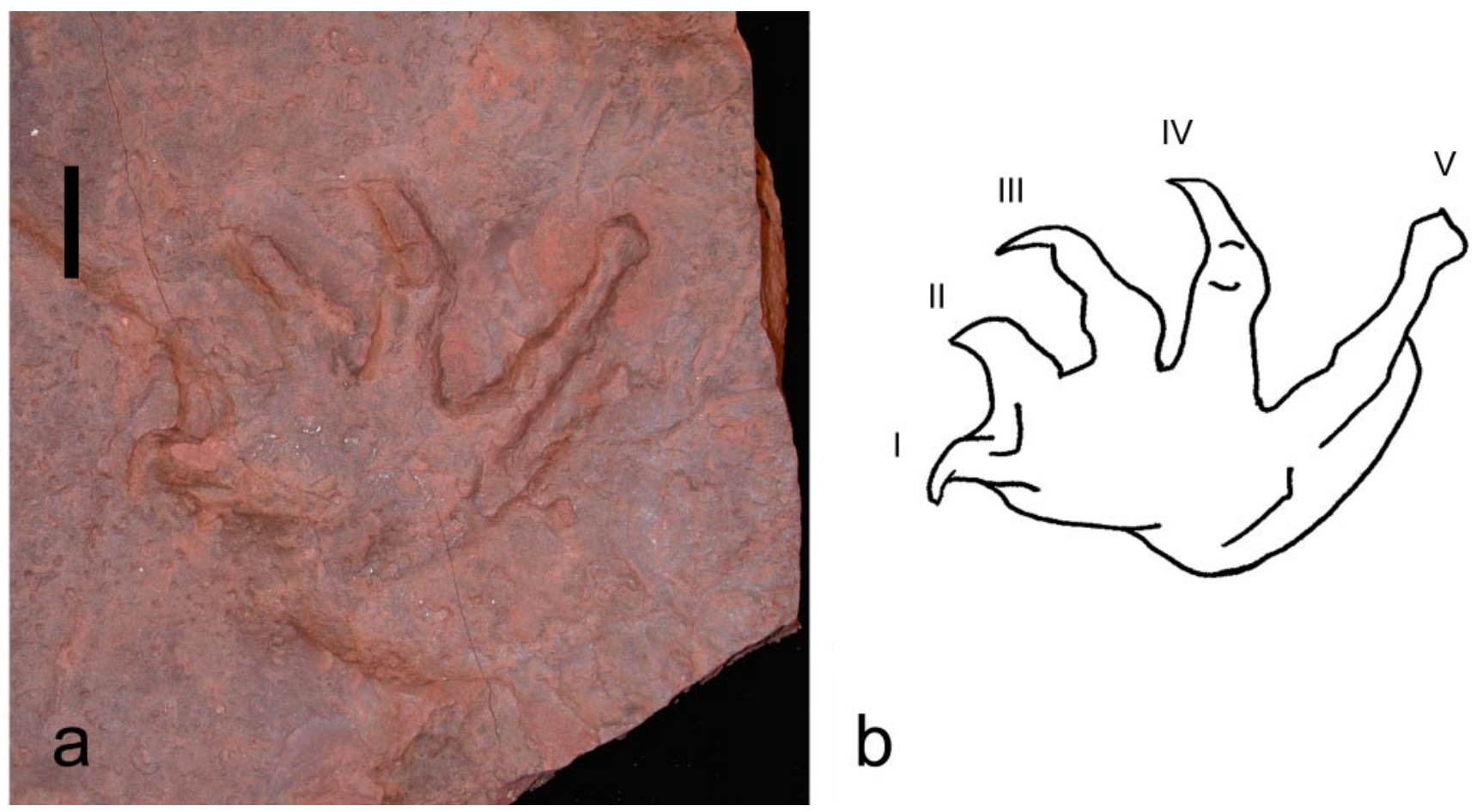

Fig. 4 (a) Pes of Pseudobradypus ichnosp. (NBMG 10128/2, counterpart to footprint P2 on NBMG 10128/3). Footprint impression in concave epirelief. (b) Sketch of Pseudobradypus ichnosp. pes. Scale bar $1 \mathrm{~cm}$

Table 1. Pseudobradypus ichnosp. trackway (NBMG 10128/3). M2 represents a manus footprint. The footprints labeled with the letter 'P' represent pes footprints. Digit length measurements for either pes or manus footprints are not included due to the inconsistent curvature of the digits. The digits of the footprints, excluding P2, P4, and M2, may appear broken, missing, or very poorly preserved. All measurements are based on methods used by Leonardi (1987).

\begin{tabular}{lccccccccc}
\hline Footprint: & P1 & P2 & P3 & P4 & P5 & P6 & P7 & ?M1 & M2 \\
\hline Length (mm): & - & 35 & ?3 & 36 & - & 40 & - & - & 25 \\
Width (mm): & - & 41 & - & 34 & - & 43 & - & - & 35 \\
Number of digits preserved: & 3 & 5 & 2 & 5 & - & $? 5$ & 3 & - & 4 \\
Sole or palm length (mm) & - & 15 & - & 16 & - & 15 & - & - & 11 \\
Sole or palm width (mm) & - & 25 & - & 25 & - & 28 & - & - & 20 \\
\hline
\end{tabular}

Stride: $130 \mathrm{~mm}(\mathrm{P} 2-\mathrm{P} 4)$ 
trackway footprints are in convex hyporelief. The approximate stride of the pedes is $130 \mathrm{~mm}$. Stride measurements could only be taken from the centre of the sole of footprint $\mathrm{P} 2$ to the centre of the sole of footprint $\mathrm{P} 4$. Due to poor preservation, it is difficult to determine if some of the footprints are part of the trackway being measured. Therefore, pace and pace angulation, length and width, as well as further stride measurements were not calculated.

Remarks: The overall size, shape, and number of digits on the footprints of the NBMG specimens 10128/2 and 10128/3 are comparable to the ichnogenus Pseudobradypus. Distinguishing features of Pseudobradypus, as described by Carman (1927), Sternberg (1933), and Haubold (1971), include the pes being larger in size than the manus, acuminating claws on digits I to IV, fairly rounded sole impressions, a laterally extended digit $\mathrm{V}$, and digits increasing in length from I to IV (with digit $\mathrm{V}$ having the same length as digit IV). The pes and manus are also pentadactyl. On the trackway specimen (NBMG 10128/3), there is one preserved manus (M2), with only four digits present. The manus, however, is not complete as a result of poor preservation.

The footprints on the trackway specimen are also semiplantigrade and, therefore, the sole (or palm) impression is not as long as those described by Haubold (1971) and earlier by Matthew (1903a, b, 1905). The curvature of the digits and claws of the footprints, as well as the bulbous digit $\mathrm{V}$ of the pes footprints are likely extramorphological features, which occurred as a result of the trackmaker's gait and speed, as well as the footprint preservation process and the nature of the substrate (Peabody 1948). Additionally, the type of gait of the trackmaker from specimen NBMG 10128/3 is uncertain. The one manus (M2) that is preserved behind the pes either suggests the trackmaker had an unusual gait, or it further displays the overall poor preservation of the trackway. Footprints P2, P4, and P7 all appear on the left side of the trackmaker with digits IV and V on the left side of the footprints, curving inward towards the midline. The footprints appearing on the right side of the trackmaker are more problematic due to a lack of preserved digits. Footprints P6 and M2 appear on the right side of the trackmaker, but this cannot be confirmed due to broken digits. Pseudobradypus trackways often preserve a tail drag. This feature is not seen on the Enragé Formation slab.

\section{CONCLUSION}

Documented vertebrate footprints and trackways are relatively rare in New Brunswick, a surprising fact given the extent of Carboniferous exposure in the eastern part of the province. Nova Scotia has produced numerous vertebrate trackways from the Joggins area (Sarjeant and Mossman 1978), Cape Breton Island (Keighley and Pickerill 1998) and Horton Bluff (Lucas et al. 2004). The New Brunswick record of skeletal remains of Carboniferous tetrapods is also poor compared to Nova Scotia (Calder 1998) with only a few unpublished or unverified re- cords known to us. The paucity of the New Brunswick record may be, in part, due to less intensive investigation, which has proven to be the case in other taxonomic groups.

The footprints found near Green Creek, Upper Rockport, New Brunswick, are located in one of four known Carboniferous vertebrate footprint localities in New Brunswick; Heron Island (Ells 1881; Harington et al. 2005), Lepreau (Sarjeant and Stringer 1978), "Fern Ledges”, Saint John (Matthew 1910) and the Maringouin Peninsula. The Heron Island footprints (CMN 10013) are Mississippian, earliest Namurian, and likely represent the oldest vertebrate (possibly amphibian) trackway from New Brunswick (Fig. 2). Falcon-Lang et al. (2007) described Pseudobradypus from the Pennsylvanian, basal Langsettian Grande Anse Formation on the Maringouin Peninsula. The trackways are preserved on two slabs with 114 prints that allowed a detailed analysis of the morphology. The authors considered the specimens represent the earliest evidence for the origin of reptiles. The tetrapod footprints from Upper Rockport, also identified as Pseudobradypus, and possibly of reptile origin, are of unspecified Namurian age, likely Mississippian, and older than the fossils described from the Grande Anse Formation by as much as 11 million years. Although only a few well-preserved prints are found on the Enragé Formation slab described here, they may represent even earlier evidence of amniotes, and like the Grande Anse footprints, predating the appearance of reptiles based on skeletal remains from Joggins (Calder 1998).

\section{ACKNOWLEDGEMENTS}

Thanks to Martin Gibling and his students (Dalhousie University) for being the first to recognize the tracks in the field and to NATMAP field trip leaders Sue Johnson and Clint St. Peter. Special thanks to David Mossman (Mount Allison University) for helpful discussions and valuable contributions during the entire project. The authors also express their appreciation to Spencer Lucas (New Mexico Museum of Natural History and Science) for discussions on the fossil footprints and for the helpful review of the manuscript. Howard Falcon-Lang generously provided information about his new fossil discovery in New Brunswick. We acknowledge a grant from the New Brunswick Environmental Trust Fund to study significant fossil sites in New Brunswick.

\section{REFERENCES}

AвеL, O. 1935. Vorzeitliche Lebensspuren. Gustav Fischer, Jena. 644 p.

BARR, S.M., AND WhITE, C.E. 2005. Bedrock geology of the Musquash Area (NTS 21 G/01), Saint John, Charlotte, and Kings Counties, New Brunswick. New Brunswick Department of Natural Resources, Minerals, Policy and Planning Division, Plate 2005-26, scale 1:50 000.

Calder, J.H.1998. The Carboniferous Evolution of Nova 
Scotia. In Lyell: the Past is the Key to the Present. Edited by D.J. Blundell and A.C. Scott. Geological Society, London, Special Publications 143, pp. 261-302.

Calder J.H., Rygel,M.C., Ryan, R.J. Falcon-Lang, H.J., AND Herbert, B.L. 2005. Stratigraphy and sedimentology of early Pennsylvanian red beds at Lower Cove, Nova Scotia, Canada: the Little River Formation with redefinition of the Joggins Formation. Atlantic Geology, 41, pp. 143-167.

Carman, J.E. 1927. Fossil footprints from the Pennsylvanian System in Ohio. Geological Society of America Bulletin, 38, pp. 385-396.

ELLS, R.W. 1881. Report on the Geology of Northern New Brunswick embracing portions of the counties of Restigouche, Gloucester and Northumberland. Geological Survey of Canada, Report of Progress for 1879-80, pp. 1D-47D.

Falcon-Lang, H., ANd Miller, R.F. 2007. Palaeoenvironments and palaeoecology of the Early Pennsylvanian Lancaster Formation ("Fern Ledges") of Saint John, New Brunswick, Canada. Journal of the Geological Society, London, 164, pp. 945-957.

Falcon-Lang, H.J., Benton, M.J., And Stimson, M. 2007. Ecology of earliest reptiles inferred from basal Pennsylvanian trackways. Journal of the Geological Society, London, 164, pp. 1113-1118.

GLAESSNER, M.F. 1957. Palaeozoic arthropod trails from Australia. Paläeontologische Zeitschrift, 31, pp. 103-109.

HänTZsCHeL, W. 1975. Trace fossils and problematica. Treatise on Invertebrate Paleontology Part W. The Geological Society of America and the University of Kansas Press. 105 p.

Harington, C.R., Foster, H., Holmes, R., And Currie, P J. 2005. Photographic Catalogue of Trackways in the Canadian Museum of Nature, Syllogeus 74. Canadian Museum of Nature, Ottawa. 151 p.

Haubold, H. 1971. Ichnia Amphibiorum et Reptiliorum fossilium. Handbuch der Paloherpetologie, Part 18. Fisher, Stuttgart. $124 \mathrm{p}$.

Haubold, H., Allen, A., Prescott, T., Buta, R.J., LaceField, J.A., Minkin, S.C., ANd Relihan, B.A. 2005. Interpretation of the Tetrapod Footprints from the Early Pennsylvanian of Alabama. In Pennsylvanian Footprints in the Black Warrior Basin of Alabama. Edited by R.J. Buta, A.K. Rindsberg, and D.C. Kopaska-Merkel. Alabama Paleontolgical Society Monograph 1, pp. 75-111.

Keighley, D.G., AND Pickerill, R.K. 1998. Systematic ichnology of the Mabou and Cumberland groups (Carboniferous) of western Cape Breton Island, eastern Canada, 2: surface markings. Atlantic Geology, 34, pp. 83-112.
Leonardi, G. 1987. Glossary and Manual of Tetrapod Footprint Palaeoichnology. Brasil. Departamento Nacional da Produçào Mineral. 75 p.

Lucas, S.G., Hunt, A.P., Mansky, C., and Calder, J.H. 2004. The oldest tetrapod footprint ichnofauna, from the Lower Mississippian Horton Bluff Formation, Nova Scotia, Canada. Geological Society of America Abstracts with Programs, 36, p. 66.

MatThew, G.F. 1903a. New Genera of Batrachian Footprints of the Carboniferous System in Eastern Canada. Canadian Record of Science, 9, pp. 99-111.

Matthew, G.F. 1903b. An attempt to classify Palaeozoic Batrachian footprints. Transactions of the Royal Society of Canada, 9, pp. 109-121.

Matthew, G.F. 1905. New Species and a new Genus of Batrachian Footprints of the Carboniferous System in Eastern Canada. Transactions of the Royal Society of Canada, 10, pp. 77-122.

Matthew, G.F. 1910. Remarkable forms of the Little River Group. Transactions of the Royal Society of Canada, 3, pp. 115-133.

New Brunswick Department of Natural Recources 2007. Lexicon Database: Lexicon of the Bedrock Nomenclature of New Brunswick Stratigraphy. URL $<$ http://www.gnb.ca/ 0078/minerals/Bedrock_Nomenclature_NB-e.asp $>$, October 2007.

Peabody, F.E. 1948. Reptile and amphibian trackways from the Moenkopi Formation of Arizona and Utah. University of California Publications, Bulletin of the Department of Geological Sciences, 27, pp, 295-468.

SaRJEANT, W.A.S., and Mossman, D.J. 1978. Vertebrate footprints from the Carboniferous sediments of Nova Scotia: A historical review and description of newly discovered forms. Palaeogeography, Palaeoclimatology, Palaeoecology, 23, pp. 279-306.

SarJeant, W.A.S., and Stringer, P. 1978. Triassic reptile tracks in the Lepreau Formation, southern New Brunswick, Canada. Canadian Journal of Earth Sciences, 15, pp. 594-602.

Sternberg, C.M. 1933. Carboniferous tracks from Nova Scotia. Geological Society of America Bulletin, 44, pp. 951-964.

St. Peter, C., And Johnson, S. 1997. Maritimes Basin Project, Southeastern New Brunswick NATMAP Field Trip. New Brunswick Department of Natural Resources and Energy, Mineral and Energy Division. 53 p.

Editorial responsibility: Ron K. Pickerill 